\title{
Social culture as the basis of the teacher's activity in inclusive education system of the university
}

\author{
Alexander Legkonogih ${ }^{1 *}$, Galina Mezinova ${ }^{1}$, Svetlana Popova ${ }^{1}$, and Yulia Ribalka ${ }^{1}$ \\ ${ }^{1}$ Don State Technical University, 344022, Rostov-on-Don, Russia
}

\begin{abstract}
The purpose of the article is to reveal the essence of social culture as an integral part of the teaching process in a higher educational institution in the aspect of the inclusive education development and the formation of a high social responsibility of a teacher. The authors identified the main criteria for assessing the social culture of a university in relation to expanding the boundaries of inclusive education and introducing innovative programs within university programs. The study is based on the development of the Code of Inclusive Education Social Culture, Don State Technical University. The results of the study were presented by the authors in scientific publications, who confirm the relevance of inclusion in the educational activities of the university.
\end{abstract}

\section{Introduction}

The phenomenon of social culture as the basis for the teacher's activities in a university in inclusive education today is viewed through the prism of many areas - pedagogy, psychology, public relations and communications. However, this should be reflected in the social work of all subjects of the educational process, which determines the professional competencies development for inclusive education of the university.

The relevance of the issue is emphasized in the scientific works of many foreign and domestic authors. So, there is an interest of Tony Booth, Melvin Ainskow's work, revealing the essence of inclusion as a social problem and as a social phenomenon, requiring the innovative approaches and integration development into social culture, including education. In an article by authors from Kazakhstan (Booth, Tony and Melvin Ainscow, 2013), we highlighted the features of inclusive education as a philosophy of social behavior, as an innovation coming from all subjects of the social space that are directly or indirectly related to this social phenomenon.

A.I. Polyansky, V.D. Martirosyan, "within the education system, inclusive culture becomes a special philosophy when the values of inclusion are accepted and shared by all participants in the educational space" (Polyansky, A.I., and Martirosyan, V.D., 2018, p.7). Inclusion in the university is an integral part of the educational process, image and professional status of the university in the social space.

\footnotetext{
*Corresponding author: lan-666-121285@mail.ru
} 
Improving the culture of teacher's behavior in inclusion is a manifestation of a unique social responsibility, trust, respect for human diversity, it is a special human factor, human capital that needs to be developed, improved and promoted in society today. The university, using its own intellectual and information and communication resources, is able to accumulate and not only participate in this process, but also attract the public.

The educational process at the university can only be considered inclusive when the subject himself is fully included in the social culture of the university, by deeply immersing himself in the awareness of the problem, in understanding his own importance in society and the need to explain to the public cultural values in relation to inclusive people.

"Decisions in the field of inclusive education development make significant updates to the structure of education and change the educational space at the regional and sectoral levels, reflecting on the structure of investments, restructuring of organizations, the structure of the proposals' portfolio for the development of inclusive educational process and the corresponding psychological and pedagogical technologies" (Ryapisova, A.G. , 2017, p. 11).

M.I. Dirie emphasizes that "a teacher must have a certain set of specific qualities, starting from the search for new ways of developing the educational process, the need for continuous self-development, the elevation of one's own social functions, and ending with professional mobility and adaptability to the information society" (Dirie, M.I., 2018, p. 42). The teacher in inclusive education is one of the main subjects that directly affect the development of social culture - the culture of the university in relation to inclusive people.

\section{Wording of the problem}

"The formation of inclusive education, the possibility of receiving it and the structuring of a full-fledged process of transferring this education is the primary task of a modern sociallyoriented university" [Legkonogih, A.N., Popova, S.L., Kunshenko, I.A., Lubentsova, T.A., and Dziuba, E.A., 2019 , p. 155]. Today, Don State Technical University (DSTU) has the resource potential, experience and skills in shaping the social culture of the university in relation to inclusive education. This is manifested in the creation of an inclusive education platform, the mission of which is based on the idea - "the ability of a person with special needs to get full educational and social experience together with "non-inclusive" people. All available information and communication resources of the university are used, including the university's website with a special section on inclusive education, social networks, and the work of the inclusive education department. All together, "emphasizes the status and social orientation of the university and distinguishes it from a number of regional higher education institutions" [Legkonogih, A.N., Popova, S.L., Kunshenko, I.A., Lubentsova, T.A., and Dziuba, E.A., 2019, p. 157].

Everyone understands the importance of the issue, but the tools of work in inclusive education are not enough, therefore the importance of developing professional competencies and the University's Code of Social Culture is substantiated.

\section{Research methods}

Empirical analysis has become the main method for studying the need to develop a Code of Social Culture for Inclusive Education as a system of professional values of the Don Technical University. A questionnaire was developed with open and closed questions, the purpose of which was to find out how much teachers are ready to introduce new professional competencies in inclusive education of a university, and also to follow the Code of Social Culture of Inclusive Education. 
The survey was attended by university teachers ( 28 people) and 4-year undergraduate students ( 83 people) in 2019. The total number is 111 people. The questions were arranged in such a way as to obtain the most truthful answers and information for the development of the Code of Social Culture of Inclusive Education of the University.

\section{Research results}

1. Is there a need to develop and implement a Code of Social Culture for Inclusive Education at DSTU? The total number of positive answers was $80 \%$.

2. Can you influence the improvement of the university in the direction of inclusive education? The total number of positive responses is only $44 \%$.

3. Do you know anything about the work of DSTU in inclusive education? Only teachers answered positively - $19 \%$, the majority chose the option "I am at a loss to answer" $-67 \%$.

4. What are the main directions of inclusive education? The majority of respondents identified distance education, individual programs and the use of digital technologies in inclusive education as the necessity and importance of integrating an inclusive and "noninclusive" university community due to the specifics of the audience.

5. What innovative, informational and communication tools can be used in inclusive university education? Respondents are sure that they can turn out to be effective: computer technology, social networks, special online programs, electronic textbooks, and demonstration products.

6. What can the Code of Social Culture of Inclusive Education give the university? 25\% believe that the Code will increase the university's communications with the public, including media. 19\% indicated lobbying interests of DSTU in the Ministry of General Education of the Rostov Region as an indicator of effectiveness. The option "development of social responsibility and attracting sponsors, investors and socially significant organizations" - showed $11 \%$, other options cited by respondents, in the aggregate, collected $45 \%$.

Opinions on the importance of developing inclusive education at the university and the need for changes taking place against this background have been mixed on the part of the faculty of the Don State Technical University.

Firstly, criticism of the decisions made concerned the required fundamental changes in the university infrastructure and the development of such spatial sites that would allow inclusive and "non-inclusive" people to coexist.

Secondly, the ambiguous remarks regarding the competency-based approach to the development of the inclusive education social culture concerned the attitudes and / or standards of professional education at universities and the impossibility of independent changes in competencies by the faculty of the university.

Thirdly, the social culture of inclusive education is interpreted by many teachers from the standpoint of either sociology and social work, or work on public relations, or in the context of university management decisions.

However, our study was reduced not to the technical parameters of the inclusive education development, but to the social culture of the university scientific community and the development of such a cultural base that will allow many generations of students and teachers to participate in inclusion and integrate all available tools in the development of the social culture of the university.

The social culture of the university in inclusive education cannot be considered only through the prism of certain areas of the university's activity or people's livelihoods. This is a large-scale phenomenon that applies to the whole society and undertakings in this regard, first of all, arise in education. 
The statement of O.M. Buzskyi "that the basic principle of any management, including social, is to achieve goals by preserving the set parameters or the mode of functioning of the system" (Buzskyi, O.M., 2013, p. 47). Thus, professional cultural competencies can be attributed to a certain system, which all subjects of the educational process of DSTU must adhere to.

In this direction, professional competencies are summarized that will contribute to the special education of the teachers' social culture in inclusive education, in particular:

- the ability to apply innovative educational tools, in particular, digital communications, in order to achieve the greatest effectiveness of teaching and establish psychological contact with inclusive students;

- possession of the ability to use and develop the capabilities of the university educational space and innovative pedagogical technologies to ensure and exercise the same access rights to the educational process of inclusive and "non-inclusive" students;

- possession of the ability to use and expand the capabilities of the university educational environment to implement the individual educational needs of inclusive students and ensure the quality of the university's social culture.

\section{Conclusion}

The competencies developed and supplemented by the authors of this article can be prescribed at the level of the Ministry of Science and Higher Education of the Russian Federation and incorporated into the educational standards of the Curriculum in all areas and profiles of study at the university.

Recommended structure of the Code of Social Culture at the Don State Technical University: Abstract; Main section; Tools; Comments Functions of the DSTU Department on Inclusive Education.

The University's Code of Social Culture will be the fundamental basis for the further work and development of inclusive university education. The implementation of the Code does not require attracting additional investments, which is significant for the university, while the results will be obvious.

\section{References}

1. Summary of E-dialogue on "Creating an Inclusive Society: Practical strategies to promote social inclusion" (organized by DPSD, UNDESA, 2007). Information on https://www.un.org/esa/socdev/egms/docs/ 2009 / Ghana / inclusive-society.pdf (accessed: 07/10/2019).

2. O.M. Buzskyi, Cultural policy strategies in the context of communication development, Education. The science. Innovation: Southern Dimension, 3(29), 45-51 (2013).

3. Booth, Tony and Mel Ainscow, Indicators of inclusion: a practical guide (Ed. 2nd. in Vogana, Regional Research Center inclusive education (CSIE), Moscow, 2013).

4. M.I. Dirie, The information culture of a modern teacher as a condition for the development of readiness for the innovative technologies use, Bulletin of Samara State Technical University. Series: Psychological Sciences, 1(37), 41-50 (2018).

5. A.Z. Zhunusova, A.S. Ilyasova, and D.O. Abisheva, Inclusion as an innovation in education, Materials of the VI International Scientific and Practical Conference, 2015, Publisher: LLC “Printing Center KAN”, 221-224 (2015). 
6. A.N. Legkonogih, S.L. Popova, I.A. Kunshenko, T.A. Lubentsova, and E.A. Dziuba, The Concept of innovation in the socio-pedagogical technologies of inclusive education, Human capital, 5(125), 153-161 (2019)

7. A.I. Polyansky, and V.D. Martirosyan, Inclusive Culture in an Educational Organization, Scientific works of Moscow Humanitarian University, 1, 7 (2018).

8. A.G. Ryapisova, Inclusive education as a systemic innovation, Bulletin of the Novosibirsk State Pedagogical University, 1, 7-20 (2017).

9. N.V. Starovoit, Inclusive culture of an educational organization: approaches to understanding and formation, Concept, 8, 31-35 (2016.) 